\title{
Facile Synthesis and Characterization of Some New 5-ethylidene-Thiazolidine-2,4-diones and their Antimicrobial Evaluation
}

\author{
PAYAL C. JOSHI, D. R. CHEJARA and D. H. MAHAJAN*1 \\ Department of Chemistry, Uka Tarsadia University, Surat 394350, Gujarat, ${ }^{1}$ Department of Chemistry, Government Science \\ College Vankal, Surat 394430, Gujarat, India
}

Joshi et al.: Synthesis and Antimicrobial Evaluation of Thiazolidine-2,4-Diones

\begin{abstract}
A series of novel 5-ethylidene-thiazolidine-2,4-diones derivatives were synthesized by the knoevenagel condensation of aromatic ketone and $\mathrm{N}$-substituted thiazolidinedione-2,4-diones. Use of KAl(SO4)2•12(H2O) i.e. Alum for the reaction makes this synthesis facile because of the some advantageous impacts viz. nontoxicity, efficient catalytic ability and lower cost of alum. Substitution of arylidene moiety at the position 5 on the thiazolidine-2,4-diones nucleus was carried out in this facile approach. Synthesized derivatives were characterized using various analytical tools and antimicrobial evaluation thereof was performed against Gram-positive, Gram negative bacteria and a fungal strain. All synthesized compounds showed moderate to very good activity against the microorganisms that they were tested for.
\end{abstract}

Key words: Alum, antimicrobial evaluation, 5-ethylidene-thiazolidine-2,4-diones, knovenagel condensation

Thiazolidine is a privileged class of compounds having many biological activities. Thiazolidine-2,4dione derivatives found as basic pharmacophore for variety of biological activities such as antibacterial and antifunga ${ }^{[1,2]}$, anticancer, analgesic, aldose reductase inhibitors $^{[3]}$ antiinflammatory, antituberculosis, antitumor $^{[4]}$, cardiotonic ${ }^{[5]}$ and antidiabetic activity ${ }^{[6]}$. Now a days the group of heterocyclic compounds such as thiazolidine-2,4-dione, 2-imino-4-thiazolidinone, 4-thioxo-thiazolidine-2,4-dione and 2-thioxo-1,3thiazolidine- 4-one (rhodanine) have been found as an interesting candidate to work on because of their pharmacological properties ${ }^{[7-12]}$.

In the recent years, bacterial infections have been increased considerably. In human civilization, bacteria are the main source of most deadly diseases and widespread epidemics. Some of the bacterial diseases such as tuberculosis, typhus, plague, diphtheria, typhoid fever, cholera, dysentery, and pneumonia have taken a high toll on humanity ${ }^{[13]}$. Improper and repeated use of certain antibiotics is the main cause of bacterial resistance. Bacteria become resistant to chemotherapeutic agents by destruction or inactivation of the drug, prevention of the penetration of the target site within the microbe and alteration of drug target

*Address for correspondence

E-mail:mahajandh@gmail.com sites $^{[14,15]}$. Furthermore, antimicrobial therapy for infection control has been focused due to increasing bacterial resistance to antibiotics ${ }^{[16]}$. Antibiotics are formed synthetically by bacteria and fungi which suppressing the growth of microorganisms ${ }^{[17]}$. At present, new antibiotics are to be discovered which are active against multidrug-resistant.

Several literature reports are there on thiazolidine conjugates wherein they showed number of biological activities on getting various substituents on different positions of thiazolidine ring ${ }^{[18]}$. Medicinal chemistry is an important field of research for the discovery of new active molecules using heterocyclic moieties that increases biological activity ${ }^{[19]}$. Introducing arylidene groups at the position 5 of the thiazolidine ring by using alum has also been reported where in alum was used as catalyst and was found as an effective promoter for the synthesis of 5-arylidine-2,4-thiazolidinediones ${ }^{[20,21]}$. With this in view strategy has been made to synthesize

This is an open access article distributed under the terms of the Creative Commons Attribution-NonCommercial-ShareAlike 3.0 License, which allows others to remix, tweak, and build upon the work non-commercially, as long as the author is credited and the new creations are licensed under the identical terms

Accepted 29 September 2020

Revised 22 September 2020

Received 08 April 2020

Indian J Pharm Sci 2020;82(5):871-880 
some novel compounds based on heterocyclic moiety i.e. thiazolidine and evaluation thereof for antimicrobial activity against different Gram positive bacteria e.g. Staphylococcus Aureus and Streptococcus Pyogenes bacteria, Gram negative bacteria e.g. Escherichia Coli and Pseudomonas Aeruginosa. Further the synthesized conjugates were also studied for their anti-fungal activity against Candida albicans. To the best of our knowledge this is the first time that modification of the thiazolidine is carried out using various substituents and derivatives were studied for antimicrobial evaluation.

\section{MTERIALS AND METHODS}

All the chemicals were supplied by SD fine and used as received. All reactions were monitored by thin layer chromatography (TLC) by using silica gel $60 \mathrm{~F}_{254}$ plates. Melting points were determined using melting point apparatus. Infra-red spectra were recorded on perkinElmer Fourier-transform (FT) Spectrophotometer. 1H Nuclear Magnetic Resonance (NMR) and 13C NMR spectra were recorded on FT-NMR spectrometer model Bruker Avance-II 400 NMR Spectrometer, using dimethyl sulfoxide- $\mathrm{d}_{6}$ as solvent. The chemical shifts were reported in units (ppm). The following abbreviation have been used s (singlet), $d$ (doublet), $\mathrm{t}$ (triplet), $\mathrm{m}$ (multiplet) for indicate the peak multiplicity in $1 \mathrm{H}$ NMR data.

\section{General synthetic procedure of 2,4-Thiazolidinedione (1):}

To a $250 \mathrm{ml}$ three neck flask outfitted with a thermometer, a stirrer and a condenser, 2-chloroacetic acid $(37.8 \mathrm{~g}, 0.4 \mathrm{~mol})$, thiourea $(30.4 \mathrm{~g}, 0.4 \mathrm{~mol})$ and water $(100 \mathrm{ml})$ were added This mixture was stirred at room temperature for at least $1 \mathrm{~h}$, and then was heated to reflux. The progress of the reaction was monitored by TLC (elution- chloroform:methanol- 20:1) until the reaction was completed $(3 \mathrm{~h})$. Then the solution was allowed to cool at room temperature. Obtained pale yellow crystalline solid was filtered and washed with water and was re-crystalized from water (decolorized with activated carbon) to get pure white crystals. Yield: $79 \%$, melting point (MP) $124-125^{\circ}$.

\section{General synthetic procedure of 2-chloro-N-(phenyl) acetamide (2):}

To a well stirred solution of aniline $(1.13 \mathrm{ml}, 0.0106$ mol) and $\mathrm{K}_{2} \mathrm{CO}_{3}(5.24 \mathrm{~g}, 0.038 \mathrm{~mol})$ in dry $\mathrm{CH}_{2} \mathrm{Cl}_{2}$ (40 mL), chloroacetyl chloride (1 ml, $0.0126 \mathrm{~mol}$ ) was added drop wise at $0^{\circ}$. The mixture was stirred at room temperature for 6-7 h. After completion of the reaction, excess of DCM was evaporated in rotary evaporator. The solid precipitates were collected and washed with excess of water and crystallized by using methanol/ acetone. Yield: $80 \%$, MP 134-136.

\section{General synthetic procedure of 2-(2,4-dioxothiazolidin-3-yl)-N-(phenyl) acetamide (3):}

A mixture of thiazolidine-2,4-dione $(0.88 \mathrm{~g}$, $0.0075 \mathrm{~mol}$ ), 2-chloro-N-(phenyl)acetamide $(0.93 \mathrm{~g}, 0.005 \mathrm{~mol})$ and sodium bicarbonate $(0.84 \mathrm{~g}$, $0.01 \mathrm{~mol}$ ) were dissolved in Dimethylformamide $(15 \mathrm{ml})$ and stirred at room temperature for overnight. After completion of the reaction which was confirmation by TLC (eluent- 7:3- hexane:ethyl acetate), the reaction mixture was poured into water $(125 \mathrm{ml})$. The product was extracted in organic layer using ethyl acetate followed by solvent distillation of access solvent and crystallization using methanol/acetone. Yield: $80 \%$, MP $189-190^{\circ}$.

\section{General Synthetic procedure of 5-ethylidene-2,4- thiazolidinedione derivatives (2B1-2B10):}

A mixture of aromatic Ketone $(0.001 \mathrm{~mol})$, 2-(2,4-dioxothiazolidin-3-yl)-N-(phenyl) acetamide $(0.001 \mathrm{~mol})$ and water $(10 \mathrm{ml})$ were taken in flask, to this reaction mixture, alum (10 mol \%) was added. The reaction mixture was heated to reflux for the appropriate time as shown in Table 1. The progress of reaction was monitore by TLC using ethyl acetate: $n$-hexane (1:9) as a solvent system. After the completion of the reaction, the mixture was cooled to room temperature and poured into crushed ice to get solid product. Obtained product was filtered dried and re-crystalized using ethanol to give 5-ethylidene-2,4-thiazolidenedione $2 \mathrm{~B} 1-2 \mathrm{~B} 15$ in good to excellent yield (Fig. 1).

\section{Characterization of N-(4-bromophenyl)-2- (2,4-dioxo-5-(1-phenylethylidene) thiazolidin-3-yl) acetamide (2B1Br):}

IR $\left(\mathrm{KBr}, \mathrm{cm}^{-1}\right): 2937 \quad(\mathrm{CH}, \quad$ aliphatic $), 3054$ $(\mathrm{CH}$, aromatic), $1736(\mathrm{C}=\mathrm{O}), 1596(\mathrm{C}=\mathrm{C}), 690(\mathrm{CS})$, $1174(\mathrm{CN}), 3242(\mathrm{NH}), 1270$ (COC). 1H NMR (400MHz, $\delta$, ppm, Dimethyl sulfoxide(DMSO)-d $\left.\mathrm{d}_{6}\right): 4.80$ $\left(\mathrm{s}, 2 \mathrm{H}, \mathrm{CH}_{2}\right), 2.40\left(\mathrm{~s}, 3 \mathrm{H}, \mathrm{CH}_{3}\right), 10.50(\mathrm{~s}, 1 \mathrm{H}, \mathrm{NH})$, 6.8-7.3 (m, 5H, Ar-H), 7.6 (d, 1H, Ar-H), 7.72 (d, 1H, Ar-H). ${ }^{13} \mathrm{C}$ NMR (400 MHz, $\delta$, ppm, DMSO-d $)$ : 13.6, 49.9, 115.4, 121.8, 121.9, 122.3, 126.3, 126.4, 127.9, 


\begin{tabular}{|c|c|c|c|c|c|c|c|}
\hline \multirow[t]{3}{*}{ Compounds } & \multirow[t]{3}{*}{ Ketone (R) } & \multirow[t]{3}{*}{$\begin{array}{c}\text { Aniline } \\
\text { derivatives }\end{array}$} & \multicolumn{2}{|c|}{ Gram positive bacteria } & \multicolumn{2}{|c|}{ Gram negative bacteria } & \multirow[t]{2}{*}{ Fungi } \\
\hline & & & & & MIC $(\mu \mathrm{G} /$ & & \\
\hline & & & S.a & S.p & E.c & P.a & C.a \\
\hline & & $X=F$ & 16 & 32 & 16 & 16 & 16 \\
\hline \multirow[t]{3}{*}{ 2B1 } & $\mathrm{CH}_{3}$ & $\mathrm{X}=\mathrm{Cl}$ & 32 & 16 & 32 & 16 & 16 \\
\hline & & $\mathrm{X}=\mathrm{Br}$ & 16 & 16 & 32 & 32 & 16 \\
\hline & & $X=F$ & 8 & 8 & 8 & 8 & 16 \\
\hline \multirow[t]{3}{*}{$2 \mathrm{~B} 2$} & $4-B r$ & $\mathrm{X}=\mathrm{Cl}$ & 4 & 8 & 4 & 8 & 16 \\
\hline & & $\mathrm{X}=\mathrm{Br}$ & 8 & 8 & 8 & 8 & 16 \\
\hline & & $X=F$ & 16 & 8 & 16 & 8 & 16 \\
\hline \multirow[t]{3}{*}{ 2B3 } & $4-\mathrm{OH}$ & $\mathrm{X}=\mathrm{Cl}$ & 16 & 16 & 8 & 8 & 16 \\
\hline & & $\mathrm{X}=\mathrm{Br}$ & 8 & 8 & 8 & 16 & 16 \\
\hline & & $X=F$ & 16 & 16 & 8 & 8 & 16 \\
\hline \multirow[t]{3}{*}{ 2B4 } & $2-\mathrm{OH}$ & $\mathrm{X}=\mathrm{Cl}$ & 8 & 8 & 8 & 16 & 16 \\
\hline & & $\mathrm{X}=\mathrm{Br}$ & 16 & 8 & 16 & 8 & 16 \\
\hline & & $X=F$ & 32 & 32 & 32 & 64 & 32 \\
\hline \multirow[t]{3}{*}{$2 \mathrm{~B} 5$} & $2-\mathrm{NH}_{2}$ & $\mathrm{X}=\mathrm{Cl}$ & 32 & 32 & 32 & 32 & 16 \\
\hline & & $\mathrm{X}=\mathrm{Br}$ & 32 & 64 & 32 & 32 & 16 \\
\hline & & $X=F$ & 64 & 32 & 32 & 64 & 32 \\
\hline \multirow[t]{3}{*}{$2 \mathrm{~B} 6$} & 3- $\mathrm{NH}_{2}$ & $\mathrm{X}=\mathrm{Cl}$ & 32 & 64 & 16 & 32 & 16 \\
\hline & & $\mathrm{X}=\mathrm{Br}$ & 32 & 32 & 32 & 32 & 16 \\
\hline & & $X=F$ & 32 & 64 & 32 & 16 & 16 \\
\hline \multirow[t]{3}{*}{$2 \mathrm{~B} 7$} & $4-\mathrm{NH}_{2}$ & $\mathrm{X}=\mathrm{Cl}$ & 64 & 64 & 64 & 64 & 32 \\
\hline & & $\mathrm{X}=\mathrm{Br}$ & 64 & 32 & 32 & 16 & 16 \\
\hline & & $X=F$ & 8 & 8 & 4 & 8 & 8 \\
\hline \multirow[t]{3}{*}{$2 \mathrm{~B} 8$} & $4-\mathrm{Cl}$ & $\mathrm{X}=\mathrm{Cl}$ & 8 & 8 & 8 & 8 & 8 \\
\hline & & $\mathrm{X}=\mathrm{Br}$ & 8 & 8 & 4 & 4 & 8 \\
\hline & & $X=F$ & 4 & 4 & 8 & 4 & 8 \\
\hline \multirow[t]{3}{*}{$2 \mathrm{~B} 9$} & $2,4-\mathrm{Cl}$ & $\mathrm{X}=\mathrm{Cl}$ & 4 & 4 & 4 & 4 & 4 \\
\hline & & $\mathrm{X}=\mathrm{Br}$ & 8 & 4 & 4 & 8 & 8 \\
\hline & & $X=F$ & 16 & 8 & 16 & 8 & 16 \\
\hline \multirow[t]{2}{*}{ 2B10 } & $4-\mathrm{NO}_{2}$ & $\mathrm{X}=\mathrm{Cl}$ & 16 & 16 & 8 & 8 & 16 \\
\hline & & $\mathrm{X}=\mathrm{Br}$ & 8 & 8 & 16 & 16 & 16 \\
\hline Ciprofloxacin & & & 4 & 4 & 4 & 4 & NT \\
\hline Ketoconazole & & & NT & NT & NT & NT & 4 \\
\hline
\end{tabular}

S.a. is Staphylococcus aureus, S.p. is Streptococcus pyogenes, E.c. is Escherichia coli, P.a. is Pseudomonas aeruginosa, C.a. is Candida albicans, $\mathrm{NT}$ : Not tested. $\mathrm{X}-\mathrm{NH}_{2}$ where $4 \mathrm{~F}-\mathrm{NH}_{2}$ is p-flouro anoiline, $4 \mathrm{Cl}-\mathrm{NH}_{2}$ is p-chloro aniline, $4 \mathrm{Br}-\mathrm{NH}_{2}$ is p-bromo aniline, $\mathrm{Ketone}(\mathrm{R})$ where $\mathrm{CH}_{3}$ is acetophenone, $4-\mathrm{Br}$ is p-bromo acetophenone, $4-\mathrm{OH}$ is p-hydroxy acetophenone, $2-\mathrm{OH}$ is o-hydroxy acetophenone, $2-\mathrm{NH}_{2}$ is o-amino acetophenone, $3-\mathrm{NH}_{2}$ is $\mathrm{m}$ - hydroxyl acetophenone, $4-\mathrm{NH}_{2}$ is p-hydroxy acetophenone, 4-Cl is $\mathrm{p}$-chloro acetophenone, 2,4-Cl is 2,2-di chloro acetophenone, 4- $\mathrm{NO}_{2}$ is p-nitro acetophenone.

$128.5,128.6,131.7,131.8,137.5,139.4,148.9,163.7$, 168.5, 173.3 (Fig. 2 and fig. 3).

Characterization of N-(4-fluorophenyl)-2-(5-(1(4-hydroxyphenyl) ethylidene)-2,4-dioxothiazolidin3-yl)acetamides (2B3F):

IR $\left(\mathrm{KBr}, \mathrm{cm}^{-1}\right): 2935$ (CH, aliphatic), 3055 $(\mathrm{CH}$, aromatic), $1735(\mathrm{C}=\mathrm{O}), 1595(\mathrm{C}=\mathrm{C}), 690(\mathrm{CS})$,
$1175(\mathrm{CN}), 3240(\mathrm{NH}), 1270$ (COC). ${ }^{1} \mathrm{H}$ NMR (400 $\left.\mathrm{MHz}, \delta, \mathrm{ppm}, \mathrm{DMSO}-\mathrm{d}_{6}\right): 4.76\left(\mathrm{~s}, 2 \mathrm{H}, \mathrm{CH}_{2}\right), 2.42(\mathrm{~s}, 3 \mathrm{H}$, $\left.\mathrm{CH}_{3}\right), 10.55$ (s, 1H, NH), $5.35(\mathrm{~s}, 1 \mathrm{H}, \mathrm{OH}), 6.65(\mathrm{~d}, 1 \mathrm{H}$, Ar-H), 7.21 (d, 1H, Ar-H), 7.22 (d, 1H, Ar-H), 7.60 (d, $2 \mathrm{H}, \mathrm{Ar}-\mathrm{H}) .{ }^{13} \mathrm{C}$ NMR $\left(400 \mathrm{MHz}, \delta, \mathrm{ppm}, \mathrm{DMSO}-\mathrm{d}_{6}\right)$ : $13.6,49.9,115.4,115.5,115.6,115.7,115.8,120.5$, $120.6,130.2,130.3,132.0,134.1,148.9,157.7,162.9$, 163.7, 168.5, 173.3 (Fig. 4 and fig. 5). 
www.ijpsonline.com

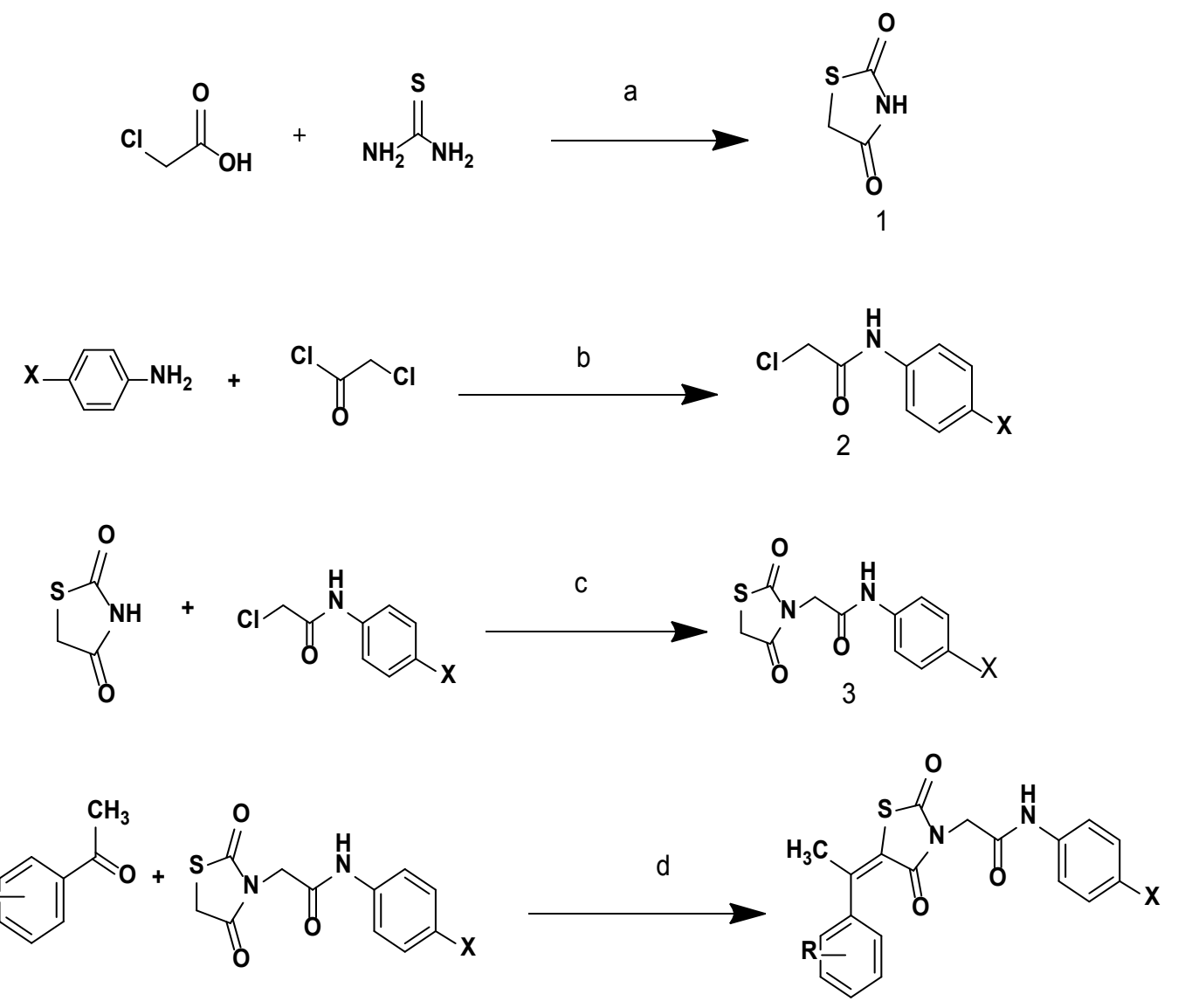

Where $\mathrm{X}=\mathrm{F}, \mathrm{Cl}, \mathrm{Br}$

2B1- 2B10

Fig. 1: Scheme for the synthesis of 5-ethylidene-2,4-thiazolidinedione derivatives (2B1-2B10)

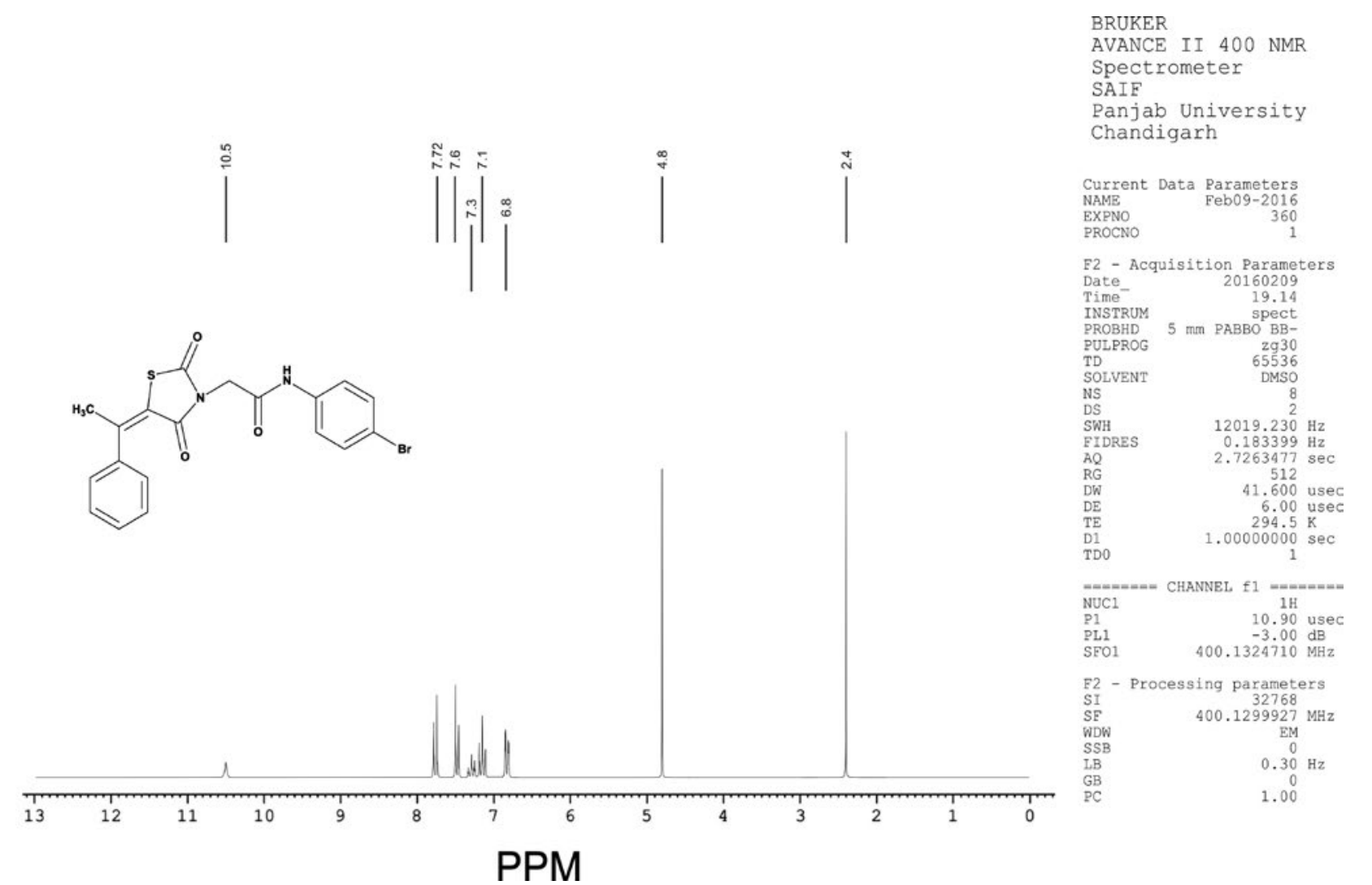

Fig.2: 1H NMR spectra of N-(4-bromophenyl)-2-(2,4-dioxo-5-(1- phenyl ethylidene) thiazolidin-3-yl)acetamide (2B1Br) 

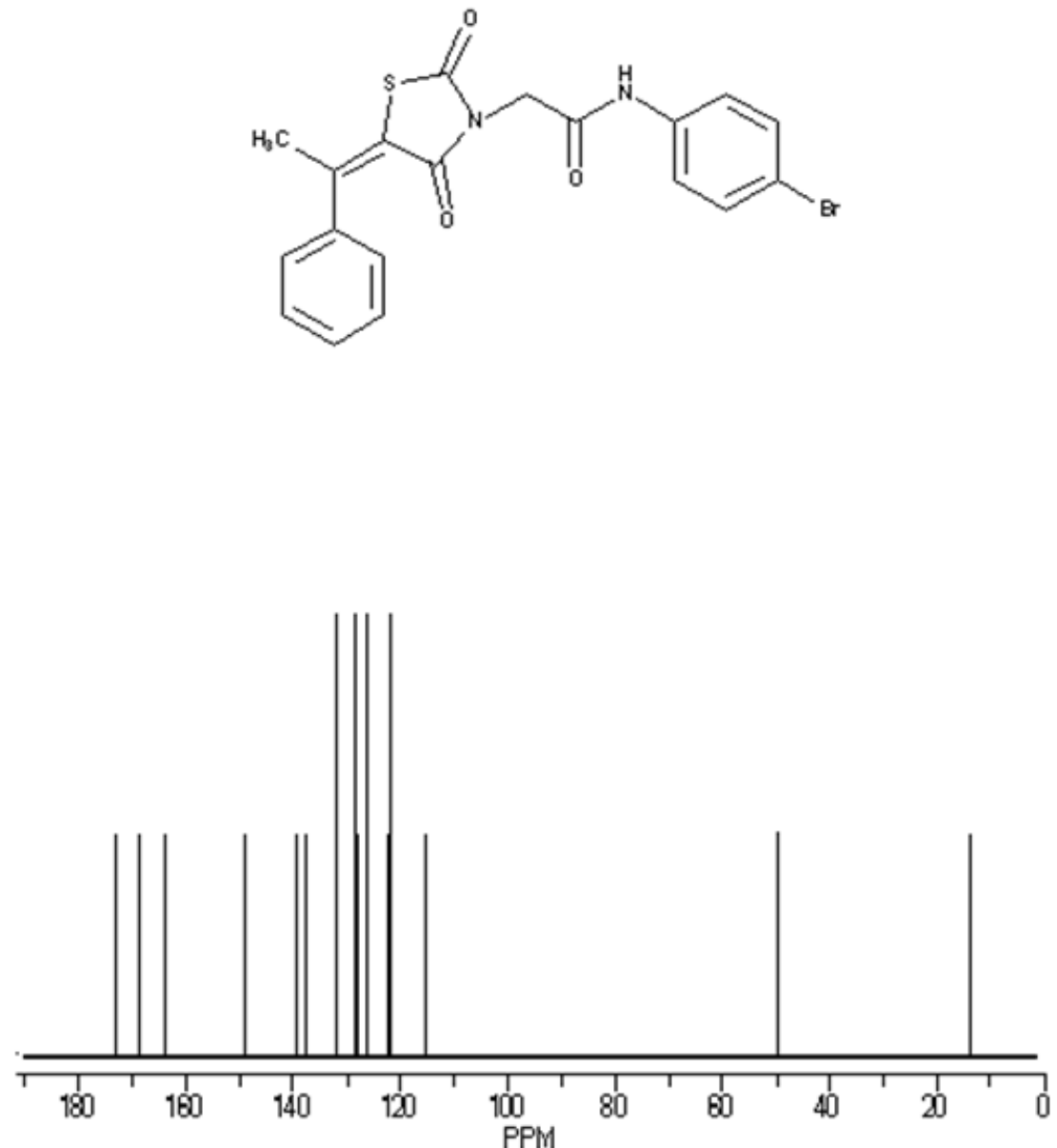

\section{BRUKER \\ AVAFCE II 400 FMR \\ Spectrometer \\ SAIF \\ Panjab Univergity Chandigarh}
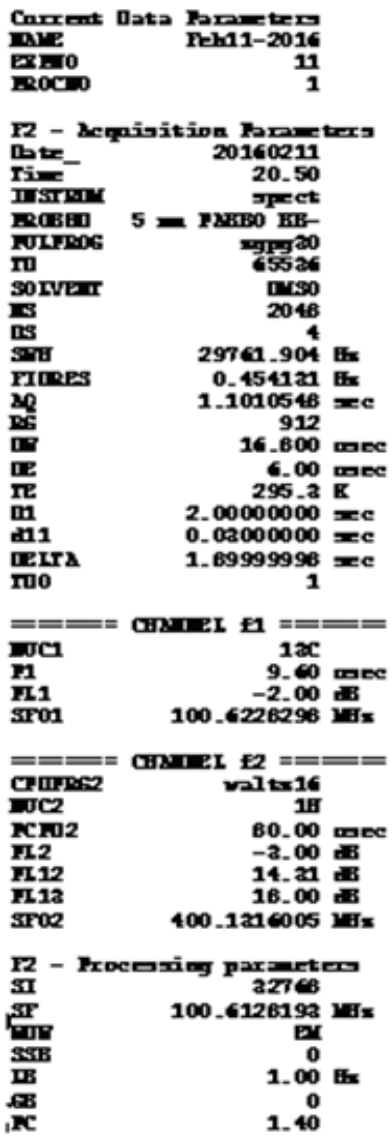

PPM

Fig.3: ${ }^{13} \mathrm{C}$ NMR spectra of N-(4-bromophenyl)-2-(2,4-dioxo-5-(1- phenyl ethylidene) thiazolidin-3-yl)acetamide (2B1Br)
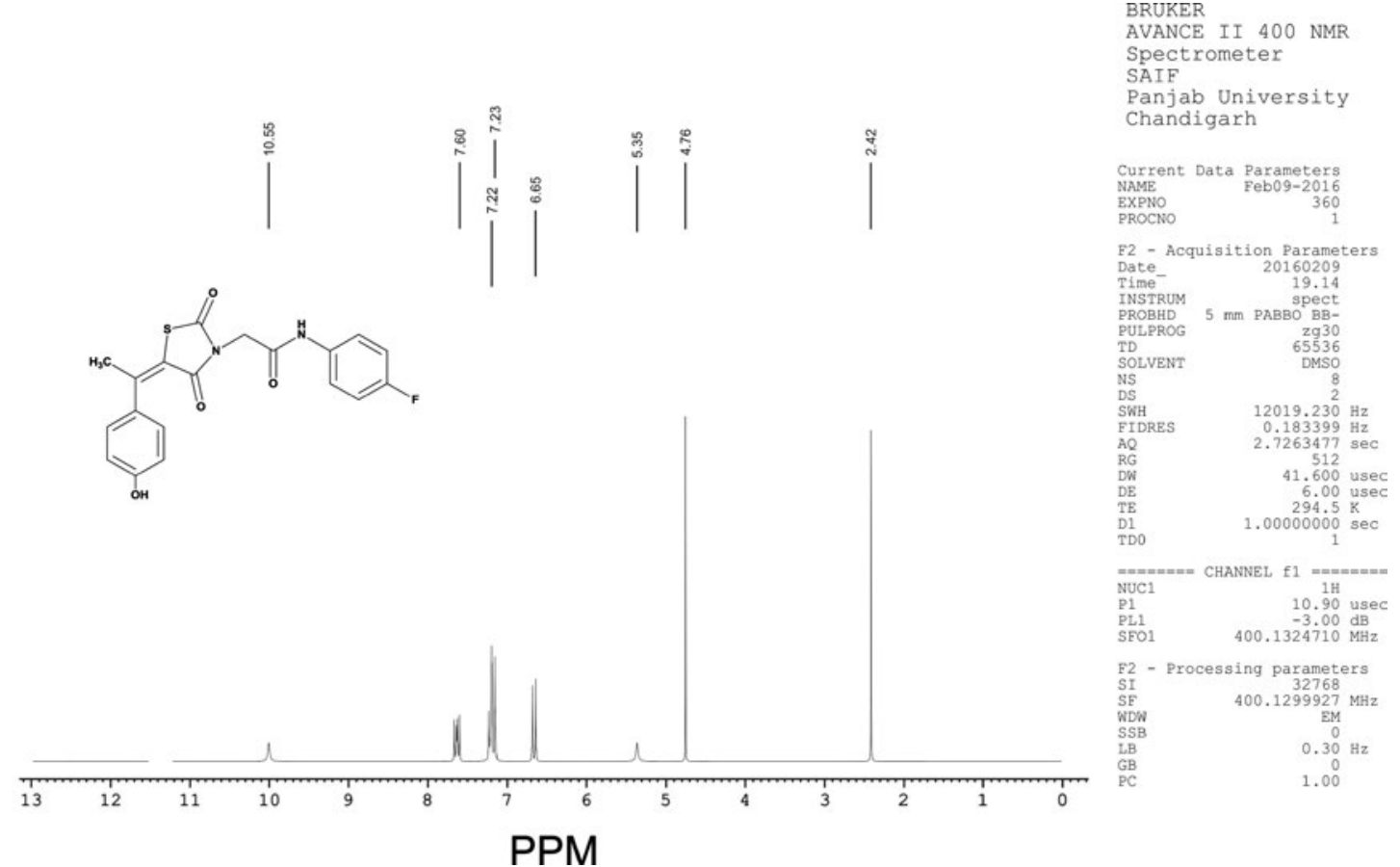

PPM

Fig.4: ${ }^{1} \mathrm{H}$ NMR spectra of N-(4-fluorophenyl)-2-(5-(1-(4-hydroxyphenyl)ethylidene)-2,4-dioxothiazolidin-3-yl)acetamides (2B3F) 
Characterization of N-(4-chlorophenyl)-2-(5-(1-(4nitrophenyl) ethylidene)-2,4-dioxothiazolidin-3-yl) acetamides (2B10Cl)

IR $\left(\mathrm{KBr}, \quad \mathrm{cm}^{-1}\right): 2945 \quad(\mathrm{CH}, \quad$ aliphatic $), \quad 3044$ $(\mathrm{CH}, \quad$ aromatic $), \quad 1733 \quad(\mathrm{C}=\mathrm{O}), \quad 1590 \quad(\mathrm{C}=\mathrm{C})$, 695 (CS), $1170(\mathrm{CN}), 3250(\mathrm{NH}), 1530$ (NO). 1H NMR (400 MHz, $\delta$, ppm, DMSO-d $\left.)_{6}\right) 4.77$ (s, 2H, $\mathrm{CH}_{2}$ ), 2.43 (s, 3H, $\left.\mathrm{CH}_{3}\right), 10.82(\mathrm{~s}, 1 \mathrm{H}, \mathrm{NH}), 8.20(\mathrm{~d}, 2 \mathrm{H}, \mathrm{Ar}-\mathrm{H})$, 7.65 (d, 2H, Ar-H), 7.47 (d, 2H, Ar-H), 7.75 (d, 2H, Ar-H). ${ }^{13} \mathrm{C}$ NMR (400 MHz, $\delta$, ppm, DMSO-d $)$ ): 13.6, 49.9, 115.4, 120.4, 120.5, 123.7, 123.8, 129.0, 129.1, $130.5,130.6,133.3,136.6,145.5,147.1,148.9,163.7$, 168.5, 173.3 (Fig. 6 and fig. 7).

\section{Antimicrobial activity}

The newly synthesized compounds were evaluated for their antibacterial activity by Broth Dilution Method. It is one of the non-automated in vitro bacterial susceptibility tests. This classic method yields a quantitative result for the amount of antimicrobial agents that is needed to inhibit growth of specific microorganisms. It is carried out in tubes, Staphylococcus Aureus (Microbial Type Culture Collection (MTCC) 96) and Streptococcus Pyogenes (MTCC 96) from Gram positive group of bacteria and Escherichia Coli (MTCC 443) and Pseudomonas Aeruginosa (MTCC 1688) from Gram negative group of bacteria for antibacterial activity were used. Candida albicans (MTCC 227) used for evaluation of antifungal activity. All MTCC Cultures were tested against synthesized and reference standard drugs. Mueller Hinton Broth was used as nutrient medium to grow and dilute the drug suspension for the test bacteria. Inoculum size for test strain was adjusted to 108 Colony Forming Unit (CFU) per ml by comparing the turbidity. Ciprofloxacin was used as the reference standard for antibacterial activity and Ketoconazole was used as the reference standard for antifungal activity. DMSO was used as diluents to get desired concentration of drugs to test upon standard bacterial strains.
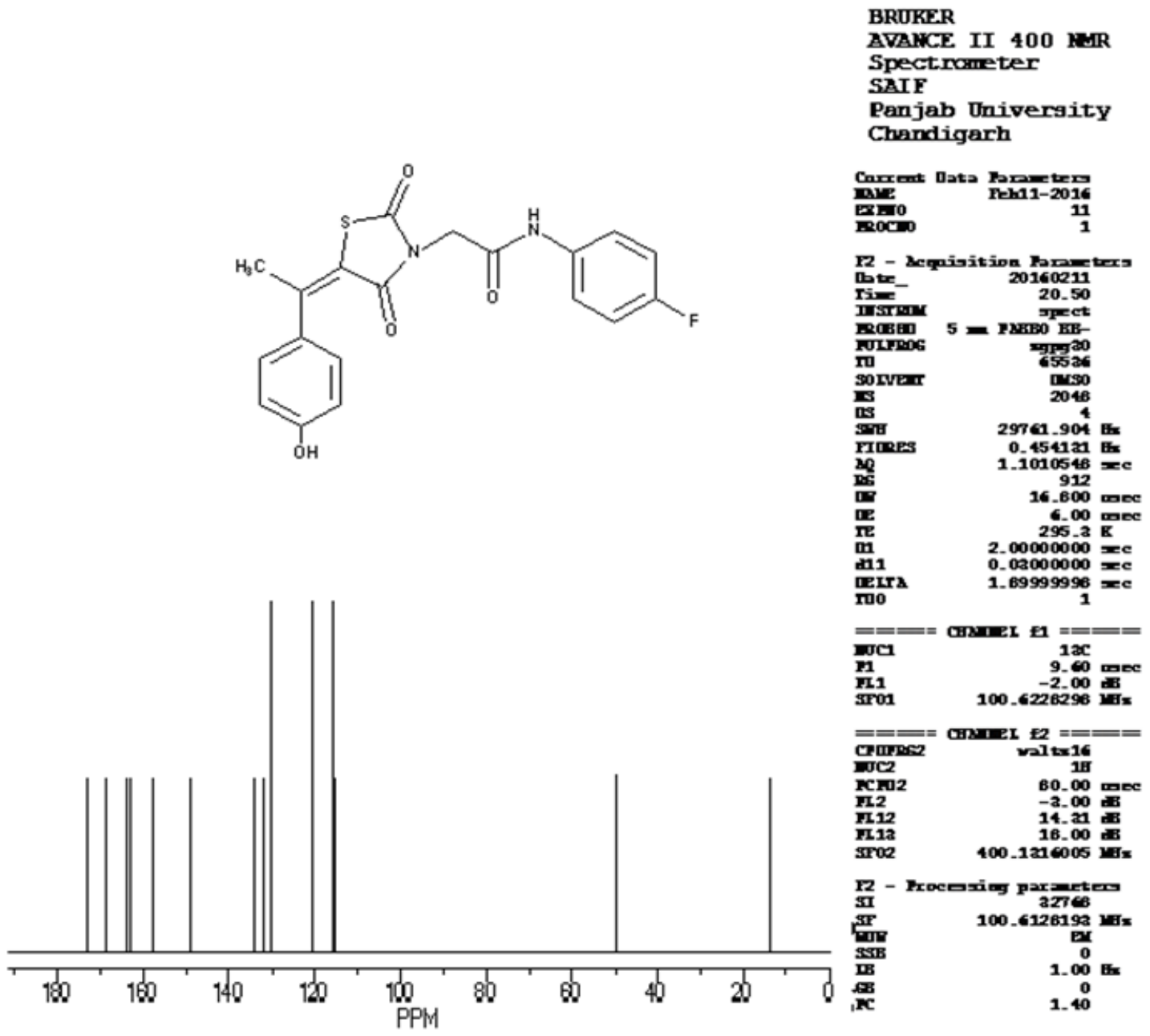

Fig.5: ${ }^{13}$ C NMR spectra of N-(4-fluorophenyl)-2-(5-(1-(4-hydroxyphenyl)ethylidene)-2,4-dioxothiazolidin-3-yl)acetamides (2B3F) 


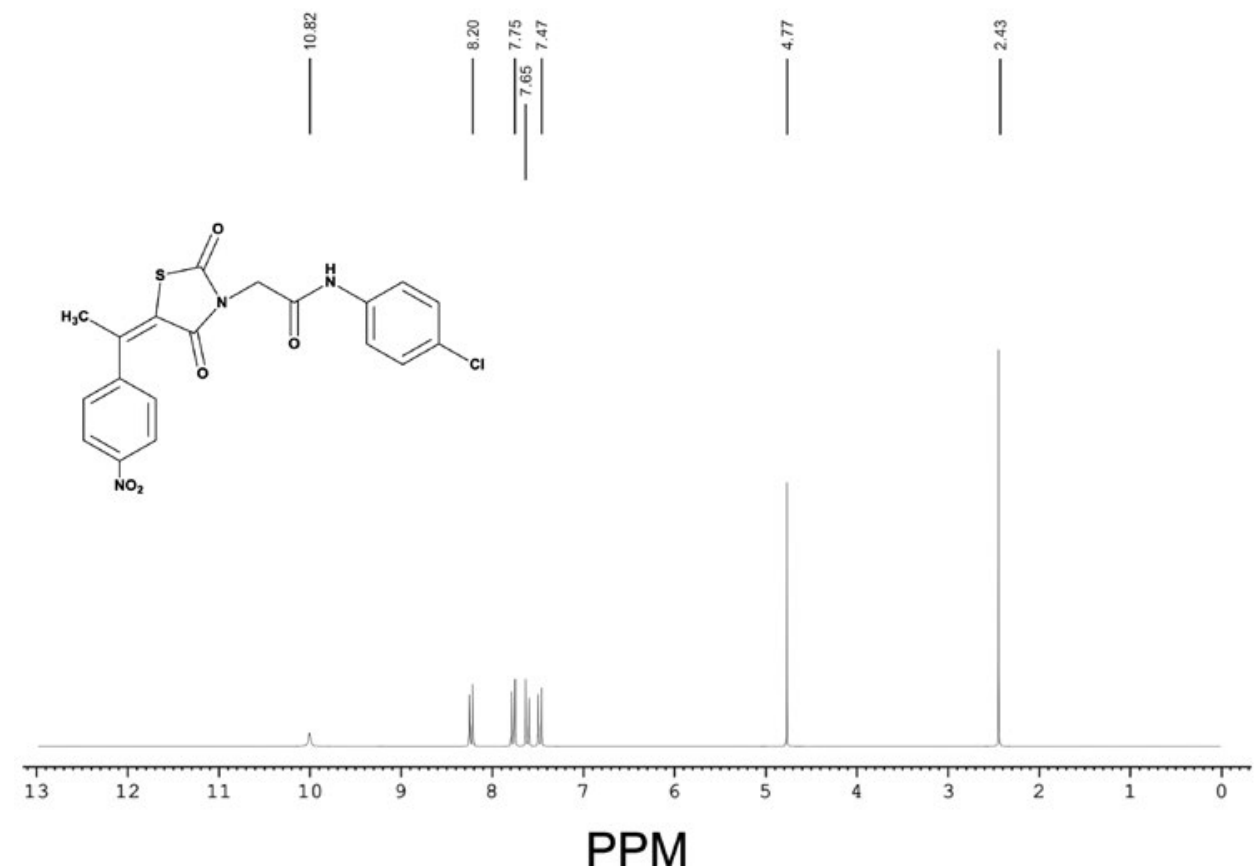

BRUKER

AVANCE II 400 NMR

Spectrometer

SAIF

Panjab University

Chandigarh

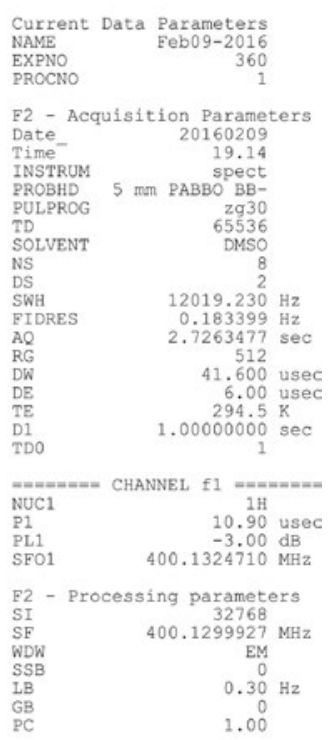

Fig.6: ${ }^{1} \mathrm{H}$ NMR spectra of N-(4-chlorophenyl)-2-(5-(1-(4-nitrophenyl) ethylidene)-2,4-dioxothiazolidin-3-yl)acetamides (2B10Cl)
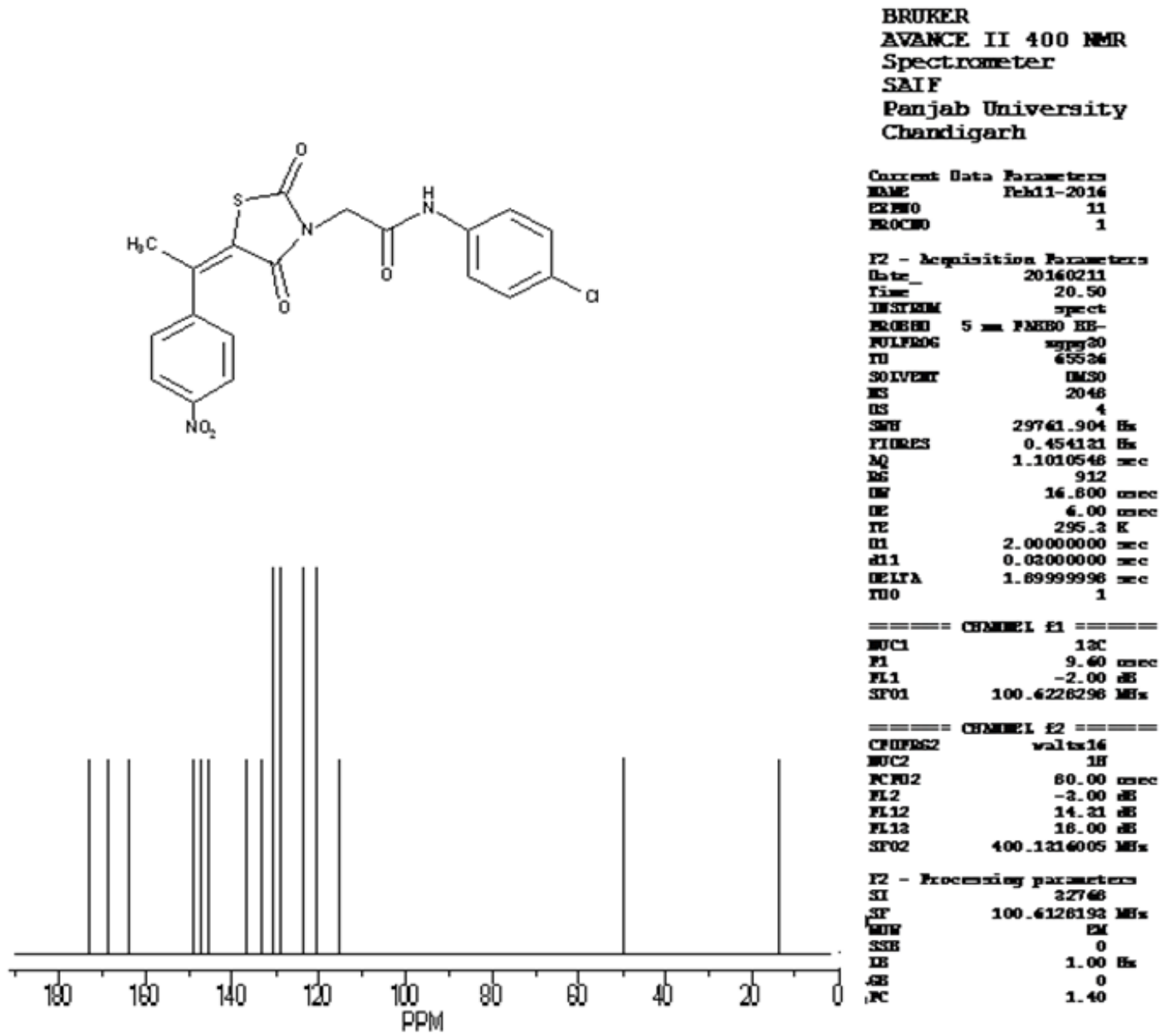

Fig.7: ${ }^{13} \mathrm{C}$ NMR spectra of N-(4-chlorophenyl)-2-(5-(1-(4-nitrophenyl) ethylidene)-2,4-dioxothiazolidin-3-yl)acetamides (2B10Cl) 
Serial dilutions were prepared in primary and secondary screening. The control tube containing no antibiotic is immediately sub cultured [before inoculation] by spreading a loopful evenly over a quarter of plate of medium, suitable for the growth of the test organism and put for incubation at $37^{\circ}$ overnight. The tubes are then incubated overnight; the Minimum inhibitory concentration (MIC) of the control organism was read to check the accuracy of the drug concentrations. The lowest concentration inhibiting growth of the organism was recorded as the MIC. The amount of growth from the control tube before incubation [which represents the original inoculum] was compared.

Each synthesized drug was diluted obtaining $2000 \mathrm{mg} / \mathrm{ml}$ concentration, as a stock solution. In primary screening $1000 \mathrm{mg} / \mathrm{ml}, 500 \mathrm{mg} / \mathrm{ml}$ and $250 \mathrm{mg} / \mathrm{ml}$ concentrations of the synthesized drugs were taken. The active components in this primary screening were further diluted to obtain $200,100,50,25,12.5$, $6.25 \mu \mathrm{g} / \mathrm{ml}$ concentrations for secondary screening. In the study, the highest dilution showing minimum $99 \%$ inhibition zone was taken as MIC.

\section{RESULTS AND DISCUSSION}

The use of solvents in Knoevenagel condensation is huge but herein present study the conditions of knovenagel condensation have been customized wherein the proposed derivatives were synthesized by condensation of aromatic ketones and $\mathrm{N}$-substituted thiazolidinedione-2,4-diones. The syntheses were carried out using alum as a catalyst yielding 5-ethylidene-thiazolidine-2,4-dione derivatives. Water was used as a medium of reaction, use of alum in water could be a great alternative to some hazardous bases and catalysts i.e. piperdine, pyridine and some solvents i.e. DMF, DMSO and toluene. Optimization of the study was carried out using different catalytic amount of alum as shown in Table 2. Study indicates the change in the concentration of catalysts leads the change in the yield of the products and also affects the reaction time. Reaction time was observed to be decreased with increasing catalyst amount [Catalyst amount (mol percentage) 5, 10, 15: Reaction time (min) 90, 60, 60 respectively]. Further the yield of the product was also seems to be increased with increasing amount of catalyst in the reaction (Table 2). Further physico chemical characterization of the synthesized compounds are given in Table 3 highlighting the compounds (2B1-2B10) having amino, chloro and nitro groups get reacted in a smooth manner to give desired product.

\begin{tabular}{|c|c|c|c|c|}
\hline Entry & $\begin{array}{l}\text { Catalyst (mol } \\
\text { percentage) }\end{array}$ & solvent & $\begin{array}{l}\text { Time } \\
(\min )\end{array}$ & Yield (\%) \\
\hline 1 & Alum (5) & $\mathrm{H}_{2} \mathrm{O}$ & 90 & 78 \\
\hline 2 & Alum (10) & $\mathrm{H}_{2} \mathrm{O}$ & 60 & 90 \\
\hline 3 & Alum (15) & $\mathrm{H}_{2} \mathrm{O}$ & 60 & 84 \\
\hline
\end{tabular}

TABLE 3: CHARACTERIZATION DATA OF THE SYNTHESIZED COMPOUNDS (2B1-2B10)

\begin{tabular}{|c|c|c|c|c|c|}
\hline Compound & $\begin{array}{l}\text { Ketone } \\
\text { (R) }\end{array}$ & $\begin{array}{l}\text { Aniline } \\
\mathrm{X}-\mathrm{NH}_{2}\end{array}$ & $\begin{array}{l}\text { Time } \\
(\min )\end{array}$ & $\begin{array}{l}\text { Yield } \\
\text { (\%) }\end{array}$ & M.P. $\left({ }^{\circ}\right)$ \\
\hline \multirow[t]{3}{*}{ 2B1 } & \multirow[t]{3}{*}{$\mathrm{CH}_{3}$} & $X=4 F$ & 80 & 80 & 197 \\
\hline & & $X=4 \mathrm{Cl}$ & 80 & 81 & 202 \\
\hline & & $X=4 \mathrm{Br}$ & 70 & 83 & 180 \\
\hline \multirow[t]{3}{*}{$2 \mathrm{~B} 2$} & \multirow[t]{3}{*}{$4-\mathrm{Br}$} & $X=4 F$ & 90 & 80 & 200 \\
\hline & & $X=4 \mathrm{Cl}$ & 80 & 85 & 227 \\
\hline & & $X=4 B r$ & 80 & 85 & 281 \\
\hline \multirow[t]{3}{*}{$2 \mathrm{~B} 3$} & \multirow[t]{3}{*}{$4-\mathrm{OH}$} & $X=4 F$ & 80 & 83 & 203 \\
\hline & & $X=4 \mathrm{Cl}$ & 70 & 87 & 237 \\
\hline & & $X=4 B r$ & 70 & 88 & 291 \\
\hline \multirow[t]{3}{*}{$2 B 4$} & \multirow[t]{3}{*}{$2-\mathrm{OH}$} & $X=4 F$ & 90 & 75 & 165 \\
\hline & & $X=4 \mathrm{Cl}$ & 80 & 82 & 210 \\
\hline & & $X=4 B r$ & 70 & 85 & 207 \\
\hline \multirow[t]{3}{*}{$2 \mathrm{~B} 5$} & \multirow[t]{3}{*}{$2-\mathrm{NH}_{2}$} & $X=4 F$ & 70 & 86 & 290 \\
\hline & & $X=4 \mathrm{Cl}$ & 80 & 80 & 248 \\
\hline & & $X=4 B r$ & 90 & 78 & 194 \\
\hline \multirow[t]{3}{*}{ 2B6 } & \multirow[t]{3}{*}{$3-\mathrm{NH}_{2}$} & $X=4 F$ & 70 & 87 & 240 \\
\hline & & $X=4 \mathrm{Cl}$ & 80 & 85 & 238 \\
\hline & & $X=4 \mathrm{Br}$ & 90 & 77 & 250 \\
\hline \multirow[t]{3}{*}{$2 \mathrm{~B} 7$} & \multirow[t]{3}{*}{$4-\mathrm{NH}_{2}$} & $X=4 F$ & 70 & 87 & 265 \\
\hline & & $X=4 C l$ & 80 & 85 & 230 \\
\hline & & $X=4 B r$ & 90 & 78 & 270 \\
\hline \multirow[t]{3}{*}{$2 \mathrm{~B} 8$} & \multirow[t]{3}{*}{$4-\mathrm{Cl}$} & $X=4 F$ & 60 & 89 & 233 \\
\hline & & $X=4 \mathrm{Cl}$ & 70 & 82 & 243 \\
\hline & & $X=4 B r$ & 70 & 82 & 263 \\
\hline \multirow[t]{3}{*}{$2 \mathrm{~B} 9$} & \multirow[t]{3}{*}{$2,4-\mathrm{Cl}$} & $X=4 F$ & 70 & 85 & 228 \\
\hline & & $X=4 \mathrm{Cl}$ & 70 & 87 & 250 \\
\hline & & $X=4 \mathrm{Br}$ & 60 & 90 & 222 \\
\hline \multirow[t]{3}{*}{ 2B10 } & \multirow[t]{3}{*}{$4-\mathrm{NO}_{2}$} & $X=4 F$ & 70 & 80 & 211 \\
\hline & & $X=4 \mathrm{Cl}$ & 80 & 84 & 241 \\
\hline & & $\mathrm{X}=4 \mathrm{Br}$ & 70 & 80 & 253 \\
\hline
\end{tabular}

M.P. is melting point, $\mathrm{X}-\mathrm{NH}_{2}$ where $4 \mathrm{~F}-\mathrm{NH}_{2}$ is $\mathrm{p}$-flouro anoiline, $4 \mathrm{Cl}$ $\mathrm{NH}_{2}$ is p-chloro aniline, $4 \mathrm{Br}-\mathrm{NH}_{2}$ is $\mathrm{p}$-bromo aniline, Ketone $(\mathrm{R})$ where $\mathrm{CH}_{3}$ is acetophenone, $4-\mathrm{Br}$ is $\mathrm{p}$-bromo acetophenone, $4-\mathrm{OH}$ is p-hydroxy acetophenone, $2-\mathrm{OH}$ is o-hydroxy acetophenone, $2-\mathrm{NH}_{2}$ is o-amino acetophenone, 3- $\mathrm{NH}_{2}$ is $\mathrm{m}$ - hydroxyl acetophenone, 4- $\mathrm{NH}_{2}$ is p-hydroxy acetophenone, $4-\mathrm{Cl}$ is $\mathrm{p}$-chloro acetophenone, $2,4-\mathrm{Cl}$ is 2,2-di chloro acetophenone, $4-\mathrm{NO}_{2}$ is $\mathrm{p}$-nitro acetophenone. 
The progress of reaction was monitored by TLC which is step wise given in the general synthetic procedure. All the melting points were taken after the recryslization of compound and are given in Table 2.

The synthesized compounds were evaluated for their antimicrobial activity against Gram positive and Gram negative bacteria. The results of antibacterial and antifungal activity of 5-ethylidene-2,4thiazolidenedione derivatives are reported in Table 3, and compared with standard drugs ciprofloxacin and ketoconazole. It is observed that the placing of arylidine moieties at position 5 of the thiazolidine ring enhanced the antimicrobial potential of the components. Inclusion of electron-withdrawing group such as halogen and nitro on phenyl ring also attributed in the antimicrobial potential. Derivatives 2B3F, 2B3Cl, 2B3Br, 2B4F, $2 \mathrm{~B} 4 \mathrm{Cl}, 2 \mathrm{~B} 4 \mathrm{Br}, 2 \mathrm{~B} 10 \mathrm{~F}, 2 \mathrm{~B} 10 \mathrm{Cl}$ and $2 \mathrm{~B} 10 \mathrm{Br}$ having hydroxyl and nitro functional groups showed good to moderate activity against all microorganisms. Compounds 2B1F, 2B1Cl and 2B1Br showed moderate activity against all microorganisms. Compounds $2 \mathrm{~B} 5 \mathrm{~F}$, 2B5Cl, 2B5Br, 2B6F, 2B6Cl, 2B6Br, 2B7F, 2B7Cl and $2 \mathrm{~B} 7 \mathrm{Br}$ having amino group showed poor activity against all gram positive and gram negative bacteria. Compounds 2B2F, 2B2Cl, 2B2Br, 2B8F, 2B8Cl and $2 \mathrm{~B} 8 \mathrm{Br}$ having halogen groups exhibited very good activity against both gram positive and gram negative bacteria. Compounds 2B9F, 2B9Cl and 2B9Br having two chloro group at $2^{\text {nd }}$ and $4^{\text {th }}$ position of aromatic ring showed excellent activity against all microorganisms. Most of the compounds showed moderate anti-fungal activity against C.albicans, Compounds 2B5F, 2B6F, $2 \mathrm{~B} 7 \mathrm{Cl}$ exhibited poor anti-fungal activity while compounds 2B8F, 2B8Cl, 2B8Br, 2B9F, 2B9Cl and $2 \mathrm{~B} 9 \mathrm{Br}$ containing chloro group exhibited excellent anti-fungal activity against C.albicans.

A series of innovative 5-ethylidene-thiazolidine-2,4dione derivatives were synthesized by the Knoevenagel condensation using alum as a catalyst. All compounds were tested against Gram-positive, Gram-negative bacteria and C. albicans. Synthesized compounds were characterized in terms of physicochemical characterization and also by using some different analytical techniques i.e. IR and $1 \mathrm{H}$ NMR and 13C NMR spectroscopy. Present study showed a sort of structural function relationship amongst the synthesized derivatives. It was noted that the compounds containing chlorine in the molecule showed the excellent antibacterial activity that indicates the potential of chlorine towards the bacteria. Furthermore, it is to be noted that attaching an electron-withdrawing functional group e.g. halogen or nitro on phenyl ring played a crucial role to enhance the activity. For the development of new antibiotics to be active against multidrug-resistant the proposed 5-ethylidenethiazolidine-2,4-dione derivatives could be a better option since the thiazolidine conjugates are already a well-known biologically active components specially when various substituents were attached on different positions of thiazolidine ring. In addition, the proposed method of synthesizing these derivatives is having many advantages e.g. easy work up procedure, better yields, low reaction time and eco friendly catalyst, made these derivatives a safer compared to the existing one.

\section{Conflict of interests:}

The authors declared no conflict of interest.

\section{Acknowledgement:}

Authors are grateful to Uka Tarsadia University for support and providing laboratory facilities and encouragement.

\section{REFERENCES}

1. Trotsko N, Przekora A, Zalewska J, Ginalska G, Paneth A, Wujec M. Synthesis and in vitro anti-proliferative and antibacterial activity of new thiazolidine-2, 4-dione derivatives. J Enzyme Inhib Med Chem 2018;33(1):17-24.

2. Malik N, Prasad D. Synthesis and Antimicrobial Evaluation of N-Substituted-5- Benzylidene-2,4-Thiazolidinedione Derivatives. Iran J Pharm Sci 2012;8(3):209-214.

3. Naim MJ, Alam MJ, Ahmad S, Nawaz F, Shrivastava N, Sahu M, et al. Therapeutic journey of 2, 4-thiazolidinediones as a versatile scaffold: An insight into structure activity relationship. Eur J Med Chem 2017;129:218-50.

4. El-Feky SA. Synthesis and anticonvulsant properties of some novel quinazolinone thiazolidine and 4-thiazolidone derivatives. Die Pharm 1993;48(12):894-6.

5. Andreani A, Rambaldi M, Locatelli A, Leoni A, Bossa R. Synthesis of lactams with potential cardiotonic activity. Eur J Med Chem 1993;28(10):825-9.

6. Cantello BC, Cawthorne MA, Cottam GP, Duff PT, Haigh D, Hindley RM, et al. [[. omega.-(Heterocyclylamino) alkoxy] benzyl]-2, 4-thiazolidinediones as potent antihyperglycemic agents. J Med Chem 1994;37(23):3977-85.

7. Andrade AM, Lima WT, Rocha MP, Lima MC, Galdino SL, Barbosa JF, et al. Synthesis and structural study of substituted thioxothiazolidinones and thioxoimidazolidinones. Boll Chim Farm 2002;141(6):428-33.

8. El-Gaby MS, Ali GA, El-Maghraby AA, Abd El-Rahman MT, Helal MH. Synthesis, characterization and in vitro antimicrobial activity of novel 2-thioxo-4-thiazolidinones and 4,4'-bis (2-thioxo-4-thiazolidinone-3-yl) diphenylsulfones. Eur J Med Chem 2009;44(10):4148-52.

9. Lesyk RB, Zimenkovsky BS, Kaminskyy DV, Kryshchyshyn AP, Havryluk RB, Atamanyuk DV, et al. Thiazolidinone motif in anticancer drug discovery. Experience of DH LNMU 
medicinal chemistry scientific group. Biopolymers Cell. 2011;27:107-17.

10. e Silva AA, da Silva Góes AJ, de Lima WT, de Souza Maia MB. Antiedematogenic activity of two thiazolidine derivatives: N-tryptophyl-5-(3, 5-di-tert-butyl-4-hydroxybenzylidene) rhodanine (GS26) and N-tryptophyl-5-(3, 5-di-tert-butyl-4hydroxybenzylidene)-2, 4-thiazolidinedione (GS28). Chem Pharm Bull 2003;51(12):1351-5.

11. Gouveia FL, de Oliveira RM, de Oliveira TB, da Silva IM, do Nascimento SC, de Sena KX, et al. Synthesis, antimicrobial and cytotoxic activities of some 5-arylidene-4-thioxo-thiazolidine2-ones. Eur J Med Chem 2009;44(5):2038-43.

12. Vicini P, Geronikaki A, Anastasia K, Incerti M, Zani F. Synthesis and antimicrobial activity of novel 2-thiazolylimino5-arylidene-4-thiazolidinones. Bioorg Med Chem 2006;14(11):3859-64.

13. Bozdağ-Dündar O, Özgen Ö, Menteşe A, Altanlar N, Atlı O, Kendi E, et al. Synthesis and antimicrobial activity of some new thiazolyl thiazolidine-2, 4-dione derivatives. Bioorg Med Chem 2007;15(18):6012-7.

14. Tortora GJ, Funke BR. Microbiologia ArtesMedicas Sul 6th ed. Brazil: Porto Alegre; 2003.

15. da Silva IM, da Silva Filho J, Santiago PB, do Egito MS, de Souza CA, Gouveia FL, et al. Synthesis and antimicrobial activities of 5-Arylidene-thiazolidine-2, 4-dione derivatives. BioMed Res Int 2014;2014:316082.

16. Stana A, Tiperciuc B, Duma M, Vlase L, Crişan O, Pîrnău A, et al. Synthesis and Antimicrobial Activity of Some New N-substituted-5-arylidene-thiazolidine-2, 4-diones. J Heterocyclic Chem 2014;51(2):411-7.

17. Gumbo T. General principles of antimicrobial therapy. In Goodman \& Gilman's The Pharmacological Basis of Therapeutics; 2012.

18. Malik S, Upadhyaya PK, Miglani S. Thiazolidinediones: a plethro of biological load. Int J Pharm Tech Res 2011;3(1):6275.

19. Allen S, Newhouse B, Anderson AS, Fauber B, Allen A, Chantry $\mathrm{D}$, et al. Discovery and SAR of trisubstituted thiazolidinones as CCR4 antagonists. Bioorg Med Chem lett 2004;14(7):1619-24.

20. Shelke KF, Sapkal SB, Kakade GK, Sadaphal SA, Shingate BB, Shingare MS. Alum catalyzed simple and efficient synthesis of 5-arylidene-2, 4-thiazolidinedione in aqueous media. Green Chem Lett Rev 2010;3(1):17-21.

21. de Paiva RK, Silva JF, Moreira HA, Pinto OG, Camargo LT, Naves PL, et al. Synthesis, Antimicrobial Activity and Structure-Activity Relationship of Some 5-Arylidenethiazolidine-2, 4-dione Derivatives. J Braz Chem Soc 2019;30(1):164-72. 